\title{
STRATEGI JITU DAN EFEKTIF MENYELESAIKAN SOAL UJIAN NASIONAL BAHASA INGGRIS BAGI SISWA KELAS XII SMK N 1 BANGKINANG
}

\author{
Siti Niah*, Wandi Syahfutra, Ardiya, Pahmi, Agung Prasetyo Wibowo, \\ Prih Febtiningsih \\ Pendidikan Bahasa Inggris, Fakultas Keguruan dan Ilmu Pendidikan \\ Universitas Muhammadiyah Riau \\ email: sitiniah@umri.ac.id
}

\begin{abstract}
The community service that hasbeen done is aimed to give an idea and understanding of the importance of English mastery and provide motivation for the participants in relation to English mastery. Furthermore, it is done in order to make the students easy to understand English, especially on basic materials with English learning methods that are relatedto students of SMK level using the concept of English for Specific Purpose (ESP) so that later students are able to do the English Language Test of National Examination well.
\end{abstract}

Keywords: The community of public service, English for Specific Purpose, National Examination

\begin{abstract}
Abstrak
Pengabdian pada masyarakat yang dilakukan bertujuan untuk memberikan gambaran tentang betapa pentingnya pengetahuan tentang bahasa Inggris dan memberikan motivasi dalam kaitan penguasaan bahasa Inggris tersebut. Hal tersebut dilakukan agar memudahkan siswa untuk memahami bahasa Inggris terutama pada materi-materi dasar dengan metode pembelajaran bahasa Inggris yang disesuaikan dengan levelnya yang mana bagi siswa SMK menggunakan konsep English for Specific Purpose (ESP) sehingga nanti diharapkan para siswa mampu mengerjakan soal bahasa Inggris Ujian Nasional dengan baik.
\end{abstract}

Kata kunci: Pengabdian, English for Specific Purpose, Ujian Nasional

\section{PENDAHULUAN}

Salah satu aspek yang penting dalam kehidupan manusia adalah pendidikan. Dalam pendidikan manusia dapat belajar banyak hal dan pengetahuan untuk menjawab tuntutan zaman dan arus globalisasi yang kian menantang. Untuk dapat memenuhi tuntutan dan perubahan tersebut setiap pribadi diminta menyiapkan diri sedini mungkin yang diproses melalui tahaptahap pendidikan. Maju mundurnya dunia pendidikan sangat tergantung pada pengelolaan pendidikan, tenaga pengajar, peserta didik dan sarana yang digunakan dalam Pendidikan tersebut.

Dalam berkomunikasi, manusia membutuhkan sarana yaitu Bahasa. Bahasa mempunyai pengaruh yang cukup besar dalam kehidupan manusia. Bahasa Inggris merupakan salah satu Bahasa Internasional yang dibutuhkan dalam berkomunikasi dan mempunyai peranan yang sangat penting dalam menjalin hubungan dengan bangsa lainnya di era ini bahkan di Indonesia mata pelajaran Bahasa Inggris 
merupakan salah satu mata pelajaran yang diujikan dalam Ujian Nasional.

Ujian Nasioanal merupakan suatu proses wajib yang harus dilalui setiap level sekolah mulai dari SD, SMP dan SMA/SMK. Ujian Nasional adalah sistem evaluasi standar pendidikan dasar dan menengah secara nasional dan persamaan mutu tingkat pendidikan antar daerah yang dilakukan oleh Pusat Penelitian Pendidikan, Depdiknas di Indonesia berdasarkan Undang-Undang Republik Indonesia nomor 20 tahun 2003 menyatakan bahwa dalam rangka pengendalian mutu Pendidikan secara nasional dilakukan evaluasi sebagai bentuk akuntabilitas penyelenggara pendidikan kepada pihak-pihak yang berkepentingan. Lebih lanjut dinyatakan bahwa evaluasi dilakukan oleh Lembaga mandiri secara berkala, menyeluruh, transparan, dan sistematis untuk menilai pencapaian standar nasional Pendidikan dan proses pemantauan evaluasi tersebut harus dilakukan berkesimabungan.

Seperti halnya sekolah-sekolah Menengah Atas lain di kota Pekanbaru dan kota-kota besar di Indonesia, SMKN 1 Bangkinang juga berbenah diri secara terus-menerus dalam rangka meningkatkan mutu pengajaran dan pengelolaan sebagai upaya untuk menuju sekolah yang mampu bersaing secara nasional maupun internasional nantinya terutama dalam menyiapkan peserta didik dalam menghadapi Ujian Nasional.

Pelatihan Bahasa Inggris "Strategi Jitu dan Efektif Menyelesaikan Soal Bahasa Inggris Ujian Nasional Bagi Kelas XII SMKN 1 Bangkinang", merupakan salah satu upaya yang dapat dilakukan untuk meningkatkan kemampuan siswa dalam menyelesaikan soal Bahasa Inggris Ujian Nasional.

Berkaitan dengan komitmen
SMKN 1 Bangkinang r untuk
meningkatkan kemampuan bahasa
Inggris bagi siswa, bantuan penanganan
yang terencana dan terprogram kiranya
sangat dibutuhkan. Untuk itulah
program ini dirancang sebagai upaya
untuk memberikan sumbangan yang
bermanfaat bagi siswa. Pelatihan
Bahasa Inggris "Strategi Jitu dan Efektif
Menyelesaikan Soal Bahasa Inggris
Ujian Nasional Bagi Kelas XII SMKN 1
Bangkinang" ini diharapkan dapat
membantu siswa merasa senang dalam
belajar bahasa Inggris sehingga siswa
SMKN 1 Bangkinang mampu
menyelesaiakan soal Bahasa Inggris
dengan baik.

\section{METODE PENGABDIAN}

Materi pelatihan dirancang berdasarkan kebutuhan pihak instansi. Tim pelaksana pengabdian masyarakat menyesuaikan materi pelatihan dengan kebutuhan. Materi yang disampaikan pada pelatihan "Satrategi Jitu dan Efektif dalam Menyelesaikan Ujian Nasional Bahasa Inggris bagi Siswa SMKN 1 Bangkinang" poin utama yaitu tentang bagaimana adanya strategi jitu dan efektif yang diberikan sehingga para siswa mendapakan gambaran tetang ujian nasional bahasa Inggris, dengan adanya pelatihan ini siswa diharapkan termotivasi dan mempunyai beberapa stratei yang bisa mereka terapkan dalam menghadapi ujian nasioanal bahasa Ingris nantinya.

Metode yang digunakan dalam kegiatan pelatihan ini adalah metode ceramah, communicative language learning, dan problem-based learning. 1) Metode Ceramah digunakan untuk menyampaikan materi secara rinci tentang persepsi pembelajaran bahasa Inggris kepada siswa SMKN 1 Bangkinang, dan metode yang digunakan untuk mengajarkan bahasa 
Inggris sesuai program English for Spesific Purpose (ESP). 2) Metode communicative language learning digunakan untuk mengakomodasi pertanyaan atau masukan tentang topik pada materi yang telah disampaikan. 3) metode problem-based learning digunakan untuk diskusi permasalahan penguasaan bahasa Inggris sehingga peserta pelatihan dapat memahami secara langsung bagaimana strategi mereka dalam menguasai bahasa Inggris dan strategi dalam pengerjaan soal ujian nasional bahasa Inggris dengan baik.

Kegiatan diawali dengan perkenalan antara Tim pelaksana dengan peserta pelatihan yaitu siswa SMKN 1 Bangkinang, yang dilanjutkan dengan pengenalan materi latihan kepada peserta latihan. Selanjutnya melakukan kegiatan proses strategi jitu dan efektif menyelesaikan soal Bahasa Inggris Ujian Nasional. Setelah itu diakhiri dengan review singkat. Kegiatan pengabdian kepada masyarakat dilakukan pada bulan Januari-Maret 2018. Adapun rancangan jadwal pelaksanaan kegiatan pengabdian adalah sebagai berikut.

Tabel 1. Jadwal Kegiatan

\begin{tabular}{|r|l|l|l|l|}
\hline \multirow{2}{*}{ No } & \multicolumn{1}{|c|}{ Kegiatan } & \multicolumn{3}{|c|}{ Bulan } \\
\cline { 2 - 5 } & Januari & Februari & Maret \\
\hline 2 & $\begin{array}{l}\text { Lokakarya dasar- } \\
\text { dasar } \\
\text { pembelajaran } \\
\text { bahasa Inggris }\end{array}$ & $\begin{array}{l}\text { Lokakarya teknik } \\
\text { dan metode } \\
\text { pembelajaran } \\
\text { reading }\end{array}$ & & \\
\hline 3 & $\begin{array}{l}\text { Lokakarya } \\
\text { pembelajaran } \\
\text { Vocabulary dan } \\
\text { Conversation }\end{array}$ & & & \\
\hline 4 & $\begin{array}{l}\text { Pelatihan praktek } \\
\text { Speaking dengan }\end{array}$ & & & \\
\hline 5 & $\begin{array}{l}\text { Pelatihan } \\
\text { grammar. }\end{array}$ & & & \\
\hline 6 & $\begin{array}{l}\text { Pelatihan } \\
\text { pelaksanaan } \\
\text { evaluasi } \\
\text { pembelajaran. }\end{array}$ & & & \\
\hline
\end{tabular}

\section{HASIL DAN PEMBAHASAN}

Hasil kegiatan pengabdian kepada masyarakat ini mendapatkan sambutan yang sangat positif dari pihak mitra yakni SMKN 1 Bangkinang karena program ini sesuai dengan kebutuhan mereka. Bentuk sambutan yang sangat positif tersebut adalah terlihat dari partisipasi seluruh peserta pelatihan yang hadir sangat aktif dalam mengikuti seluruh proses kegiatan. Pelatihan ini dapat dilihat pada gambar 1 .

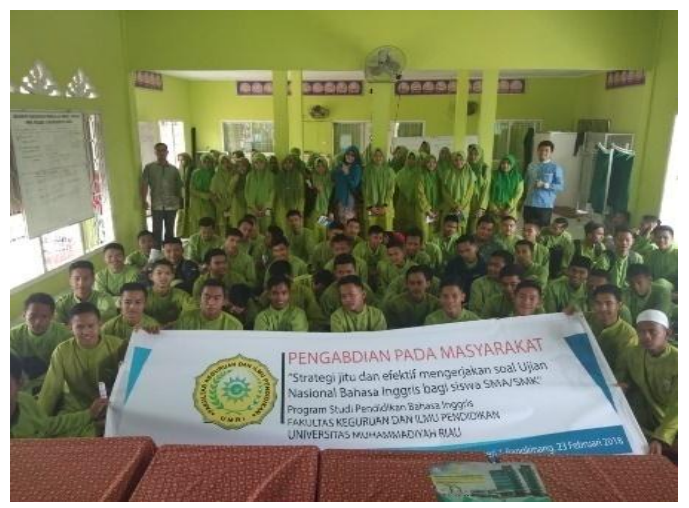

Gambar 1. Pelaksanaan pelatihan

Seluruh peserta pelatihan memiliki motivasi yang tinggi yaitu dengan sangat antusianya mereka dalam kegiatan pelatihan. Hal tersebut mengindikasikan bahwa adanya kesadaran para peserta pelatihan dalam memahami pentingnya menguasai bahasa nggris dan strategi dalam mengerjakan soal ujian nasional bahasa Inggris. Kegiatan tersebut bisa dilihat pada gambar 2 .

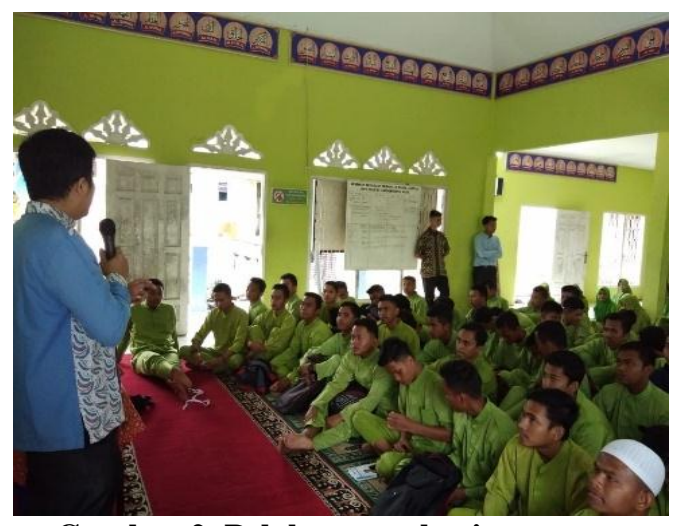

Gambar 2. Pelaksanaan kegiatan 
Peningkatan kemampuan anak didik terhadap penguasaan skil bahasa Inggris terutama di era modern saat ini harus menggunakan metode yang sesuai dengan levelnya dan adanya penggunan berbaga metode yang efektif dalam pengajaran. Hal ini dikarenakan bahasa Inggris merupakan skil yang harus dimiliki setiap orang untuk dapat memahami berbagai bidang keilmuan serta teknologi informasi agar mampu bersaing.

Berdasarkan hasil yang didapat dari kegiatan pengabdian pada masyarakat (PPM) yang telah dipaparkan, bahwa kegiatan pengabdian ini mendapat respon yang sangat baik dari para peserta. Para siswa SMKN 1 Bangkinangsangat aktif dalam setiap sesi kegiatan.

Kegiatan yang diikuti oleh peserta pengabdian berjalan dengan baik, namun kerjasama yang baik dan proaktif diantara para peserta yang sangat antusias dalam berdiskusi tentang materi yang sudah diberikan pada pelatihan tersebut, maka hal tersebut dapat menyelesaikan masalah yang dihadapi selama proses berlangsung. Keberhasilan kegiatan pengabdian ini terlihat dari adanya kemauan atau kesungguhan yang tinggi yang ditunjukkan oleh peserta melalui kegiatan selama proses berlangsung. Hal ini menunjukkan bahwa mereka merasakan manfaat dari adanya kegiatan pengabdian ini sehingga mereka menganggap penting pembelajaran bahasa Inggris diberikan kepada anak sejak awal.

\section{KESIMPULAN}

Upaya untuk meningkatkan kualitas sumber daya manusia di era modern merupakan suatu keniscayaan karena ilmu pengetahuan dan teknologi semakin maju maka seiring itu pula sumber daya manusia perlu ditingkatkan. Penguasaan bahasa asing, terutama bahasa Inggris, merupakan suatu hal yang sangat penting. Kemampuan bahasa Inggris dapat mudah dikuasai apabila dalam proses pembelajaran diajarkan dengan menggunakan metode yang efektif.

Pelatihan "strategi jitu dan efektif dalam mengerjakan soal ujian nasional bahasa Inggris bagi siswa SMKN 1 Bangkinang" merupakan salah satu upaya yang dapat dilakukan untuk meningkatkan kemampuan berbahasa Inggris siswa. Materi pelatihan yang diberikan mencakup strategi yang disesuaikan dengan level SMK yaitu English for Specific Purpose (ESP).

Upaya yang dilakukan oleh pihak sekolah yaitu SMKN 1 Bangkinang dalam hal ini untuk meningkatkan kemampuan bahasa Inggris anak didiknya dengan berkonsultasi dengan pihak terkait yaitu Program Studi Pendidikan Bahasa Inggris UMRI sudah tepat, karena dinilai mendapat manfaat dari pelatihan yang dilakukan. Sebaliknya tim pelaksana dari Program Studi Pendidikan Bahasa Inggri UMRI juga dapat menjalankan catur dharma perguruan tinggi salah satu perannya dengan pengabdian kepada masyarakat melalui pelatihan penyamaan persepsi atau cara pandang pembelajaran bahasa Inggris antara guru bahasa Inggris dan wali murid dalam untuk membantu memudahkan tercapainya tujuan sekolah tersebut.

\section{UCAPAN TERIMA KASIH}

Pelaksanaan kegiatan Pengabdian Pada Masyarakat ini tentunya tidak akan terlaksana sesuai rencana jika tanpa bantuan dari berbagai pihak. Oleh karena itu maka penulis mengucapkan terima kasih kepada seluruh pihak yang telah membantu secara materil dan moril sehingga kegiatan pengabdian ini dapat terlaksana dengan baik. Adapun 
ucapan terima kasih tersebut ditujukan

kepada:

1. Rektor UMRI

2. Ketua LPPM UMRI

3. Dekan FKIP UMRI

4. Ketua Program Studi Pendidikan Bahasa Inggris

5. Kepala SMK Negeri 1 Bangkinang

6. Majelis Guru SMK Negeri 1 Bangkinang

\section{DAFTAR PUSTAKA}

1. Brown, H. Douglas. (2001). Teaching by Principles: An Interactive Approach to Language Pedagogy ( $2^{\text {nd }}$ ed $)$. New York: Pearson Education Company.

2. Stern H. H. (1991). Fundamental Concepts of Language Teaching. USA. University Press

3. https://id.wikipedia.org/wiki/Ujian_N asional.22-01-2018.

4. https://www.zenius.net/blog/3054/tip s-belajar-un-sma-bahasa-inggris

5. http://www.geniusedukasi.com/tipsdan-strategi-menjawab-soallistening/

6. http://www.ahzaa.net/2015/11/tipsmenjawab-soal-listening-sectionun.html

7. http://aanpujiyonotimorenti.blogspot. co.id/2010/12/strategimengerjakanun-bahasa-inggris.html 